\title{
RIGHTS OF PRISONERS UNDER THE INTERNATIONAL HUMANITARIAN LAW: A CASE STUDY OF THE PALESTINIAN PRISONERS IN ISRAELI PRISON
}

\author{
Hamza A. K. Salman* \\ Noor Shuhadawati Binti Mohamad Amin**
}

\begin{abstract}
The Israeli occupation of Palestine has triggered several forms of Palestinian resistance, resulting in the detainment of Palestinians through Israel systematic policies which destroy the will of the Palestinians. This has made the issue of prisoners one of the most important concerns that the Palestinians continue to endure in their daily lives. Therefore, this study aims to clarify the role of international humanitarian law (IHL) in protecting prisoners. It also discusses the rights granted to prisoners by international treaties and conventions and Israel's application of the rules of IHL to Palestinian prisoners. This research is based on doctrinal and qualitative methods using the sources of IHL about prisoners' rights. This study also discusses the violations committed by the Israeli occupation against Palestinian prisoners, which are the inhuman treatment they are subjected to, and the passage of a group of laws that violate the rights of Palestinian prisoners. The study concludes that Israel denies Palestinians the rights as prisoners of war, describing them as illegal combatants, and claims that the convention does not apply to the occupied Palestinian territories although IHL under the Geneva Convention includes members of the resistance and organised armed forces. As a result, prisoners from the Palestinian resistance can be considered prisoners of war.
\end{abstract}

Keywords: International humanitarian law, international law, prisoners of war, Palestinian prisoners, treatment of Palestinian prisoners by Israel.

Phd Student at the Faculty of Law, National University of Malaysia (UKM) in Selangor, Malaysia. Email: hamzasalman934@gmail.com.

** Assistant Professor at the Department of civil law, Ahmad Ibrahim Kuliyyah of Laws, International Islamic University of Malaysia. Email: shuhadaamin@iium.edu.my. 


\title{
HAK-HAK BANDUAN-BANDUAN DI BAWAH UNDANG- UNDANG KEMANUSIAAN ANTARABANGSA: KAJIAN KES BANDUAN-BANDUAN PALESTIN DI PENJARA-PENJARA ISRAEL
}

\begin{abstract}
ABSTRAK
Penjajahan Israel ke atas Palestin telah mencetuskan beberapa bentuk penolakan oleh penduduk yang berakhir dengan penahanan penduduk Palestin melalui polisi-polisi sistematik Israel memusnahkan semangat penduduk terbabit. Ini telah menyebabkan isu banduan-banduan menjadi suatu kebimbangan utama yang terpaksa dilalui oleh penduduk Palestin dalan kehidupan seharian. Oleh itu, kajian ini bertujuan untuk menjelaskan peranan Undang-undang Kemanusiaan Antarabangsa (IHL) dalam melindungi banduan-banduan. Kajian ini turut membincangkan hak-hak yang diberikan kepada banduan-banduan melalui perjanjian-perjanjian antarabangsa dan konvensyenkonvensyen, dan penggunaan peraturan-peraturan IHL oleh Israel terhadap banduan-banduan Palestin. Kajian ini bersandarkan kepada kaedah doktrin dan kualitatif yang bergantung kepada sumber-sumber IHL berkenaan hak-hak banduan. Kajian ini juga membincangkan pelanggaran yang dilakukan oleh penjajahan Israel terhadap banduanbanduan Palestin yang terikat kepada perlakuan tidak berperikemanusiaan dan perlaksanaan beberapa undang-undang yang melanggar hak-hak banduan-banduan tersebut. Kajian ini menyimpulkan bahawa Israel menafikan hak-hak banduan-banduan perang kepada penduduk Palestin, menggambarkan mereka sebagai pejuang-pejuang haram dan mendakwa bahawa Konvensyen Geneva tidak terpakai terhadap wilayah-wilayah Palestin yang dijajah walaupun IHL di bawah Konvensyen Geneva, hak ini terpakai kepada anggotaanggota tentera rintangan dan terancang. Oleh itu, banduan-banduan Palestin boleh dianggap sebagai banduan-banduan perang.
\end{abstract}

Kata kunci: Undang-undang Kemanusiaan Antarabangsa, undang-undang antarabangsa, banduan-banduan perang, banduan-banduan Palestin, perlakuan terhaadap banduan-banduan Palestin oleh Israel.

\section{INTRODUCTION}

International humanitarian law (IHL) is a branch of international law that aims to regulate relations between states during the period of armed conflict, limiting the rights of the parties to the conflict by means 
of war and reducing the suffering caused by war as well as protecting and assisting victims as much as possible. IHL is based on a set of laws and conventions, namely the statute of the International Criminal Tribunal and the Hague Convention of respecting the laws and customs of war on land with attached regulations and the Four Geneva Conventions of 1946 and its protocols on the protection of civilians in wartime and armed conflicts, including resistance to occupation, in which people struggle for freedom, self-determination, and resistance against racist regimes. ${ }^{1}$

Generally, Israel refers all cases related to Palestinian detainees to military courts and detains them in its prisons. Palestinian prisoners in Israeli prisons are considered security prisoners and detainees are treated in this way as directives concerning convicted prisoners and detainees against state security, thus the Palestinian prisoners are subjected to a range of violations under this allegation. ${ }^{2}$ The definition of these prisoners as "security" prisoners, applied without distinction, has transformed thousands of Palestinians imprisoned in Israel today into a single group that poses an identical level of danger, justifying their stricter living conditions and supervision, as well as the reduced chances of early release. Unlike the general approach to prisoners, which is based on an individual assessment of a person and the level of the risk he or she poses, the State of Israel's stance toward "security" inmates is based on their group affiliation. ${ }^{3}$

On the other hand, Boaz Ganor and Ophir Falk stated that Palestinian security prisoners are a group of terrorists and the prisoners' associations provide them with increased organisational power and coordination in which they have sought to use against the prison authorities. Moreover, the differences in the treatment of security inmates and criminals are primarily on security issues. Both

1 Amer Al-Zamali, Categories Protected by International Humanitarian Law, (Cairo: Lectures on International Humanitarian Law, ICRC, 2016), 84.

2 Maher Maghari, "Alwade Alqanuniu Lil'asraa Alfilastiniiyn Fi Alsujun Al'iisrayiyliati”" (Master diss., Al-Aqsa University of Palestine, 2017), 83.

3 Abeer Bakr, "The Definition of Palestinian Prisoners in Israeli Prisons as 'Security Prisoners' - Security Semantics for Camouflaging Political Practice”, Adalah's Review, no. 5 (2009): 65. 
groups are likewise guarded by Israeli Prison Service members who have been trained to treat inmates with respect. ${ }^{4}$

The current work is an attempt to examine the protection afforded to such categories of prisoners by IHL by describing Israeli actions against the Palestinian prisoners in Israeli prisons. The analytical approach of the article is based on the analysis of these practices in light of the rules of IHL to determine whether they are applied to Palestinian prisoners in Israeli prisons or not. There will be three sections in this article. The first section will examine the general recognition of prisoners' rights under IHL, defining the protection provided by IHL to protect a prisoner of war after one falls into the hands of the detaining authority and during the period of detention. The second section will focus on the different categories of Palestinian prisoners held in Israeli prisons and whether Israel applies the Geneva Convention to them. The third section will go into detail about the physical and psychological abuses perpetrated against Palestinian prisoners in Israeli prisons and detention centres, as well as the lack of a fair trial and their exposure to laws that may be unfair to them, such as administrative detention, child detention, force-feeding laws, among others.

\section{GENERAL RECOGNITION OF PRISONERS' RIGHTS UNDER INTERNATIONAL HUMANITARIAN LAW}

IHL classifies armed conflict into international and non-international armed conflict. An armed conflict between a state and an armed group, or between armed groups is considered a non-international armed conflict, whereas international armed conflicts are between states and in the case of military occupation. ${ }^{5}$ In the context of the conflicts that broke out in the Middle East in June 1967, the Israeli army occupied the remaining Palestinian areas following the partition plan outlined in the UN Resolution 181 (II) of 1947. Consequently, Israel became a belligerent occupant of those territories and the relevant IHL

4 Boaz Ganor and Ophir Falk, "De-Radicalization in Israel's Prison System”, Studies in Conflict \& Terrorism, no. 36, Vol. 2 (2013):116-131.

5 Preethi Lolaksha Nagaveni and Amit Anand, "International and NonInternational Armed Conflicts and Application of International Humanitarian Law as Lex Specialis", Chotanagpur Law Journal, no. 1, vol. 11 (2017): 79. 
instruments became applicable to the governance of the occupation, the conduct of the occupying power, and the civilian population who were subsequently designated as "protected persons."

In cases where territory is occupied, such as Palestine, the application of IHL, particularly the Geneva Convention, ceases only with the effective end of such occupation or a comprehensive political settlement of the dispute, in accordance with the rules of general international law. ${ }^{7}$ The 1929 Geneva Prisoners of War Convention established a more thorough set of guidelines for the treatment of prisoners of war after capture compared to the short paragraphs of the Hague Regulations. It employed the inclusion by reference approach, stating that individuals entitled to prisoner of war status were all those mentioned in Articles 1, 2, and 3 of the 1907 Hague Regulations. ${ }^{8}$ The Geneva Convention, established in 1949, went much beyond this, establishing a comprehensive set of regulations controlling the treatment of prisoners of war and developing the legislation governing the legal status of privileged irregular fighters by incorporating organised resistance groups. ${ }^{9}$ Article 4 further states that prisoners of war status are extended to those individuals "who have fallen into the power of the enemy," a broader phrase than "captured" as used in the 1929 Geneva Prisoners of War Convention. It refers to the privileged warriors who are not members of the regular armed forces as "other

6 The Permanent Observer Mission of Palestine to the United Nations, "Israel's Belligerent Occupation of the Palestinian Territory, including Jerusalem and International Humanitarian Law", Paper presented to the Conference of the High Contracting Parties to the Fourth Geneva Convention on Measures to Enforce the Convention in the Occupied Palestinian Territory, including Jerusalem, Geneva, 1999, accessed Aug 14 , 2021 https://webcache.googleusercontent.com/search?q=cache:bDRHaji3jP4J :https://unispal.un.org/DPA/DPR/unispal.nsf/0/6B939C57EA9EF32785 256F33006B9F8D+\&cd=14\&hl=en\&ct=clnk\&gl=my\&lr=lang_ar\%7Cl ang_en.

7 Ibid.

8 Geneva Convention Relative to the Treatment of Prisoners of War, (adopted on 19 July 1929, entered into force 19 June 1931), Art. 1.

9 W. Thomas Mallison and Sally V. Mallison, "The Juridical Status of Irregular Combatants under the International Humanitarian Law of Armed Conflict", Case Western Reserve Journal of International Law, vol. 9 (1997): 47. 
militias and members of other volunteer corps, including those of organised resistance movements." 10

When the fighters fall into the hold of the hostile state, they are detained and prevented from continuing to fight. Therefore, IHL has established restrictions and rules governing the treatment of prisoners, guarantees them many rights on which the Detaining Power must deal with it and treat prisoners in accordance with the principles of humanity that guarantee prisoners' protection and respect. ${ }^{11}$ The Third Geneva Convention of 1949 refers to the rights and guarantees of prisoners from the moment of apprehension and during their imprisonment as follows:

\section{The Rights of Prisoners of War from the Moment They Were Arrested}

The Third Geneva Convention of 1949 grants prisoners a range of rights from the moment they were imprisoned by the Detaining Power, where they were guaranteed humane treatment from the moment they were imprisoned, including the time during search and interrogation.

\section{Protection Granted to Prisoners of War at the Moment of Their Arrest}

The Third Geneva Convention of 1949 has protected prisoners of war. It has made it clear at the beginning of the imprisonment, which is "The time when the prisoner falls under the control of the enemy state", ${ }^{12}$ i.e., from the moment the prisoner is arrested by an individual or a military unit belonging to the Detaining Power.

The contracting state is responsible for the prisoners and therefore responsible for the conduct of its military personnel and units that surrounded the prisoner, as well as the state, is responsible for the

10 Third Geneva Convention, (adopted in 1929, entered into force 12 August 1949) (GCIII), Art 4.

11 Abdul Rahman Ali Ibrahim Ghunaim, Alhimaya Alqanunia Lil'asraa Wifqan Li'ahkam Alqanun Alduwlii Alansanii Dirasa Tatbiqia Ealaa Wade Alaisraa Alfilastiniina, (Berlin: Arab Democratic Centre for Strategic, Political and Economic Studies, 2018), 46.

12 GCIII, Art 5. 
actions of its civilian citizens, who may be able to arrest the prisoner in some situation such as for paratrooper landings. ${ }^{13}$ Warring parties are prohibited from killing legitimate combatants fighting against the hostile state as soon as they stop fighting for circumstances beyond their control such as injuries, illness, or other physical or mental harm. In this case, those who cannot fight or who have been arrested can be considered prisoners of war who are entitled to the protection and guarantees prescribed from the moment they fall into the grip of the Detaining Power or hostile state. ${ }^{14}$

The Detaining Power must remove the prisoners as soon as possible to camps far from the combat zone so that they are safe from danger and do not remain in the danger zone even if temporarily unless the transfer puts them at a greater risk. ${ }^{15}$ Transfer of the prisoners of war must be done humanely, not endangered and the Detaining Power should provide the transferred prisoners of war with drinking water, food, clothing, health care and collect personal data on transferred prisoners of war. ${ }^{16}$

\section{The Protection Afforded to Prisoners of War During the Inspection and Interrogation Process}

International custom has granted the Detaining Power the right to inspect prisoners to seize items of military value, such as weapons, ammunition, maps, reconnaissance tools, military documents, etc. These matters are considered war booty, therefore, the Detaining Power has the authority to confiscate these items except for protective equipment, such as metal helmets and other personal protection. Prisoners of war keep all their personal tools and the Detaining Power must provide identity documents to all prisoners and are not allowed to

13 Yasser Ammouri, "The Legal Status of Palestinian Political Prisoners in International Law", paper presented at the United Nations International Meeting on the Palestinian Issue entitled the Issue of Palestinian Prisoners in Israeli Prisons and Detention Facilities, (Geneva: April 3, 2012), 10.

14 Mohammed Al-Shalaldeh, Alqanun Alduwliu Al'iinsaniu, (Jerusalem: Dar Al-Fikr Publishing, $1^{\text {st }}$ edn., 2005), 121.

15 GCIII, Art19.

16 Ibid., Art 20. 
withdraw military ranks, medals, money, and valuables held by detainees without receiving a receipt. ${ }^{17}$

At the time of interrogation, the prisoner is only required to give the full name, military rank, date of birth, army or squad, personal or serial number. If the prisoner is unable to give such information, similar information must be provided and if the prisoner violates this rule by choice, he or she does not benefit from the benefits granted to the prisoners according to rank or status. ${ }^{18}$ Parties to the conflict must provide all members at risk of imprisonment with an identity card containing the full name, rank, army number, identification number, and date of birth of the holders, thus the prisoner must submit this card to each application and could not be withheld arbitrarily in any way. ${ }^{19}$

Prisoners of war may not be physically or morally tortured while obtaining information from them during interrogation. The interrogation of the prisoners must be conducted in a language they understand and prisoners of war who are unable to provide information about their identity due to their physical or mental condition must be handed over to the Medical Services Department. ${ }^{20}$ Third Geneva Convention states in Article 3 of paragraph A: "Non-assault on life and physical integrity, especially murder in all forms, distortion, cruel treatment and torture". ${ }^{21}$

\section{The Rights of Prisoners During Confinement}

\section{The Right to Humane Treatment}

Prisoners must always be treated humanely and any negligence by the Detaining Power is a violation of the provisions of the Third Geneva Convention. Prisoners may not be subjected to medical and scientific experiments, in addition to the sanctity of prisoners' bodies, thus preventing humiliation with their bodies and the Detaining Power is

\footnotetext{
17 Ibid., Art 18.

18 Al-Shalaldeh, Alqanun Alduwliu Al'iinsaniu, 22.

19 Ammouri, "The Legal Status",12.

20 GCIII, Art 17.

21 Ibid., Art 3 (1) (A).
} 
not entitled to do anything that does not serve the interests of the prisoner. ${ }^{22}$

Under Article 11 of the First Additional Protocol of 1977, it is prohibited to subject the wounded, sick, and distressed at seas to any medical procedure that is not required by their health condition. The article also excludes blood donation and skin tissue donation for transplantation, provided that this is done with the consent of the prisoner without coercion or threat and for therapeutic purposes only. ${ }^{23}$ Therefore, it is clear that the Third Geneva Convention and the First Additional Protocol have denied any reprisals against all categories of protected persons who are under the authority of the hostile State for any reason. ${ }^{24}$

Furthermore, prisoners of war must retain the full civil capacity they enjoyed before the captivity, whereby the Detaining Power must not restrict these rights only to the extent required by imprisonment whether in its territory and abroad. Prisoners of war have the right to respect their personality and honour in all cases. Women prisoners should also be treated differently from male prisoners by considering their gender, endurance and placing them in comfortable detention and free of men. ${ }^{25}$ In contrast, the Detaining Power must ensure the implementation of equality to all prisoners without discrimination between prisoners on the basis of race, sex, religion, colour, or other criteria, because the conditions of prisoners are equal, thus that equality does not affect respect for military ranks, sanitary conditions, age or professional qualifications of some prisoners. ${ }^{26}$

\section{The Right to Medical Assistance, Adequate Shelter, Food and Clothing}

The Detaining Power should provide adequate food and clothing for prisoners and free medical care required by their specific health

22 Ibid., Art 13.

23 Protocol II Additional to the Geneva Conventions, (adopted 8 June 1977, entered into force 7 December 1978)(APII),Art 11.

24 Al-Shalaldeh, Alqanun Alduwliu Al'iinsaniu,125.

25 GCIII, Art 14.

26 Ibid., Art 16. 
condition..$^{27}$ The states are committed to applying all necessary health measures to keep the prison camps clean and healthy. The place should also be free from diseases and prisoners of war must have clean sanitation facilities. They must be provided with the necessary tools to clean their bodies and wash their clothes. ${ }^{28}$ The Detaining Power takes care of the prisoner's affairs free of charge, including shelter, food, and clothing, as follows:

The right to shelter requires the Detaining Power to provide appropriate conditions for prisoners in the prison areas, taking into account the customs and traditions of prisoners, provided that these places are protected from moisture with adequate light, warmth and take all means to prevent the dangers of fire. Women, on the one hand, should be placed separately from men. ${ }^{29}$

The right to food requires daily basic meals provided to prisoners that must be sufficient, of good quality, and healthy to maintain the health of prisoners, providing adequate amounts of drinking water and usable water. In the events where prisoners are involved in preparing most of their own food, they can be employed in the kitchens provided with designated dining areas. The Detaining Power is not entitled to use food as a means of discipline or punishment. ${ }^{30}$

The right to adequate clothing requires the Detaining Power to provide prisoners with clothes commensurate with the nature of the climate in the area where the prisoners are held, the obligation to replace the clothes of prisoners of war that are regularly damaged, and to provide prisoners working inside the prison with special clothing for their work. ${ }^{31}$

\section{The Right to Practice Religious, Educational, Recreational, and Sports Activities}

The Detaining Power must allow prisoners of war to practice their religious observance freely, provided that they do not deviate from the regime set by the military authorities. There must be suitable places for

\footnotetext{
27 Ibid., Art 15.

28 Ibid., Art 29.

29 Ibid., Art 25.

30 Ibid., Art 26.

31 Ibid., Art 27.
} 
religious ceremonies and the clerics detained with other prisoners must be allowed to hold religious rites among prisoners of the same faith and to distribute prisoners to camps according to the prisoners' faith and language. ${ }^{32}$ It also encourages prisoners of war to participate in activities that will fill their free time, take all measures to ensure the exercise of these activities, and provide the prisoners with the necessary tools and places for such activities. ${ }^{33}$

\section{The Right of Prisoners to Contact with the Outer World}

The Detaining Power must allow prisoners to send and receive messages and can determine this correspondence by allowing at least two or four postcards monthly. These cards have to be identical to the local forms of the Geneva Convention. The prisoners who have not received news about their families for a long time and whose families cannot send a postcard shall be allowed to send telegrams on their account. ${ }^{34}$ Prisoners can also obtain individual and group parcels containing clothing, medicines, or other supplies by mail parcel, to enable prisoners to meet their special needs, practice their religion or acquire knowledge and culture. ${ }^{35}$

\section{The Right of Prisoners to Fair Trial}

The Detaining Power must allow the prisoners to assist each other, choose a lawyer to defend them, and use the qualified interpretation services so that the prisoners can understand the lawyer's language and they must be informed of those rights before the trial begins. If a prisoner does not choose a lawyer to defend him or her, the Detaining Power does this task and provides a lawyer on his/her behalf. The lawyer defending the prisoner is granted at least two weeks from the start of the trial, has the right to visit and speak freely with the accused without the presence of an observer, and has the right to speak with all witnesses of innocence including prisoners of war. The lawyer can benefit from these facilities until the expiry of the appeal. In the event of a verdict, the Detaining Power must inform the lawyer and indicate

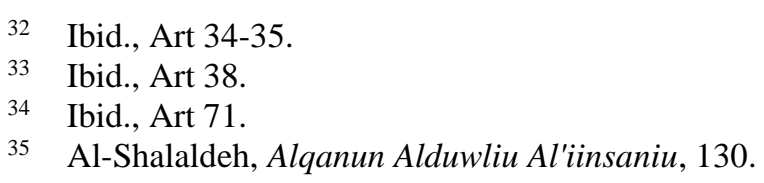


whether he can appeal, reject the appeal, or claim for revision of the judgment. Accordingly, the prisoner must be informed of the verdict in a language he or she understands, and if the prisoner is not present at the time of sentencing, the Detaining Power must inform the Protecting Power of the prisoner of war and decide whether to use his right to appeal or not. ${ }^{36}$ After addressing the general recognition of prisoners' rights and examining the protection provided to them by IHL, the next part of the article deals with the application of the Geneva Convention in Israeli prisons.

\section{TYPES OF PALESTINIAN PRISONERS IN ISRAELI PRISONS AND THE APPLICATION OF THE GENEVA CONVENTION TO THEM}

\section{Types of Palestinian Prisoners in Israeli Prisons}

Prisoners in Israeli prisons are divided into two categories: criminal prisoners and security prisoners. Administrative detainees and detainees under the Illegal Fighter Act fall into the category of security prisoners. ${ }^{37}$ The Israeli Prison Service's orders and regulations do not specify who is the criminal prisoner, but they define the security prisoner in Instructions no. (00/02/03). Most security prisoners are Palestinians, but there are a few Jews classified as security prisoners. Under the new version of the Regulations of the Israeli Prison Service, special regulations have been adopted referring to the rights, duties, and disciplinary rules of prisoners. ${ }^{38}$ They are as follows:

\section{Criminal Prisoners}

Criminal prisoners are treated under special regulations that distinguish them from other security detainees,${ }^{39}$ and this research addresses this

\footnotetext{
36 Ibid, Art 107.

37 Bakr, "The Definition", 65.

38 Ibid.

39 Murad Jadallah, "Al'iitar Alqanuniu Limueamalat Al'asraa Walmuetaqalin Alfilastiniiyn Liwayih Maslahat Alsujun Fi Eayn Alqanun Alduwalii," Badil Resource Center for Palestine Residency \& Refugee Rights, accessed Sep 2019, http://www.badil.org/ar/component/k2/item/1880-art4.html\#_ftn3.
} 
category of prisoners only as a comparison to clarify the conditions and treatment of the Palestinian prisoners and detainees.

\section{Security Prisoners}

The prison service grants the status of a security prisoner to any person convicted of a misdemeanour or detained on suspicion of a misdemeanour and has been classified based on its nature or circumstances as a blatant security misdemeanour or the motive was on national background. ${ }^{40}$ Detainees classified as such are treated under directives no. (00/02/03) called "working rules for security prisoners", where Article 1 (A) states that the directives concerning prisoners sentenced and detained against State security are superior to any other matter issued by the prison service and contrary to them. ${ }^{41}$

The role played by the Israeli Prison Service regulations is mostly contrary to international conventions, makes it an unfair tool in the hands of the various organs of the prison service to continue denying the rights of the Palestinian detainees, committing crimes against them and providing a legal cover that obscures any legal accountability process within the judicial system of the occupying power. However, the prison service regulations do not clarify the legal and procedural basis for the transfer of prisoners and detainees, which is itself a cover for the crimes committed by these units against the Palestinian prisoners of war and immunity from any meaningful legal accountability. ${ }^{42}$

Prison service orders deal with "security prisoners" according to a collective logic, regardless of age differences, health conditions, and the seriousness of the prisoner. Clause 1 (B) of the Order of the Israeli Prison Service no. (03/02/2000) clarifies the logic of the prison service, which is behind this collective classification of security prisoners by saying "There are prisoners sentenced for misdemeanours against state security, usually a real threat to state security in general, and the system and obedience in prisons in particular, in terms of the type of misdemeanours they committed, their past, their motives and their participation in operations against state security. The majority of these

\footnotetext{
40 Bakr, "The Definition", 66.

41 Jadallah, "Al'iitar Alqanuniu Limueamalat Al'asraa".

42 Ibid.
} 
prisoners are linked to terrorist organisations, and this link in itself hides special risks to the system and obedience in prison and to state security, and requires a security ban on security prisoners, their detention in isolation from criminal prisoners, and special restrictions on them in relation to their relationship with the outside world, including vacations, visits, phone calls and private meetings with spouses". ${ }^{43}$

Clause(C/3) of the Israeli Prison Service Order no. (03/02/2000), which lists hostile organisations "Terrorist", does not include any Jewish organisation. It can be said that the two exceptions that can prevent restrictions on a prisoner classified as "security prisoner" is that this prisoner was not a member of the hostile organisation, and has not helped a hostile organisation, provided a note is submitted by the

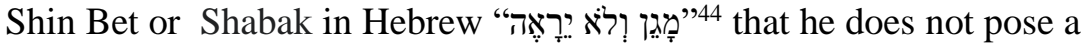
threat to security by not imposing special restrictions on him. ${ }^{45}$

There are many reasons for the occupation's pretext in the detention of Palestinians. Sometimes Palestinians are detained without any reasons or charges, yet the detention continues for years, thus no single reason can be generalised to all arrests. These arrests, which are subject to the Fourth Geneva Convention, are particularly for the protection of civilians during armed conflict or occupation. Many prisoners were arrested during resistance operations and therefore must be subject to the Third Geneva Convention of 1949 on prisoners. Some prisoners were abducted and charged and some ministers and deputies were held hostage in exchange for the release of Israeli soldier "Gilad Shalit". ${ }^{46}$ According to the Rome Statute of the International Criminal Court, these types of prisoners are victims of war crimes. There are prisoners without specific charges, as well as some detainees under the

43 Ibid.

44 Shabak or the Shin Bet: It is the Israeli Internal security service. Its motto

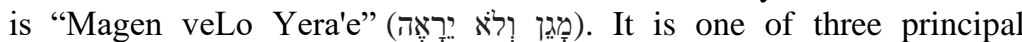
organizations of the Israeli intelligence community, alongside Aman and the Mossad.

45 Jadallah, "Al'iitar Alqanuniu Limueamalat Al'asraa".

46 Gilad Shalit is a former MIA soldier of the Israel Defense Forces who on 25 June 2006, was captured by Hamas' militants in a cross-border raid via underground tunnels near the Israeli border. Hamas held him captive for over five years, until his release on 18 October 2011 as part of a prisoner exchange deal. 
name of an illegal combatant, who are the victims of war crimes committed by the Israeli occupation. ${ }^{47}$

\section{Administrative Detainees}

Administrative detention under IHL and the Fourth Geneva Convention is defined as a deprivation of liberty on the orders of the executive rather than the judiciary, without criminal or security counts being brought against the detainee. ${ }^{48}$

Hundreds of Palestinians are arrested annually under administrative arrest warrants issued by the military commander in the Occupied Palestinian Territory against people they believe pose a threat to the security of the region and the security of the occupying power. From 2011 to 2012, the number of Palestinian administrative detainees held in Israeli prisons ranged from 250 to 300 detainees under directives no. (00/02/04) called "conditions of detention in administrative detention". Therefore, this is a clear and explicit violation of the provisions of the Hague and Geneva Conventions. ${ }^{49}$

\section{Unlawful Combatants}

Prison service regulations specify that "unlawful combatant" is every person detained in prison under an arrest warrant signed by the Chief of Staff and does not deserve to be held as a prisoner of war. Dozens of Palestinians were arrested in the occupied Gaza Strip under this law, particularly during the military aggression in December 2008 and January $2009 .{ }^{50}$

47 Mohammed Al-Nahhal, "Alhimayat Alqanuniat Alduwliat Lil'asraa Alfilastiniiyn Fi Alsujun Al'iisrayiyl”, Working Paper, Gaza, 2010, 6-7.

48 Khadija Ziada, "AlaietiqalAl'iidariu”,Dunia Al Watan, accessed Sep 6, 2019, https://pulpit.alwatanvoice.com/content/print/289335.html .

49 Jadallah, "Al'iitar Alqanuniu Limueamalat Al'asraa".

50 'QQanun Almuqatil Ghayr Alshareii' Ghita' Qadayiyun Liljarayim Al'iisrayiylia Bihaqi Shaebina",WAFA News Agency, accessed October 3 , 2019 , http://www.wafa.ps/ar_page.aspx?id=3SBLDBa602831784423a3SBLD B. 


\section{Applicability of the Geneva Convention to Palestinian Prisoners in Israeli Prisons}

The inclusion of "organised resistance movements" is based on the Second World War experience and grants authority and legitimacy to resistance activities that are comparable or identical to the wartime model. The wide phrasing made applicable to such resistance activities, "operating in or outside their own territory, even if this territory is occupied," offers a large geographical sphere of operations for such movements that were not covered in the Hague Regulations. The phrase "outside their own territory" permits resistance actions anywhere within the belligerent occupant's sovereign territory. This clause also intends to prevent members of such movements to function within the occupied territory from losing their POW status. ${ }^{51}$

The conditions of the prisoner of war in accordance with the Third Geneva Convention are applicable to the Palestinian resistance factions, and because the Zionist entity occupied this land, the Palestinian people have the right to defend it by various means. Armed resistance is one of the most important means of defence, where the Palestinian resistance movements are headed by political and military leaders and each movement has insignia, flag and military weapons that carry out military operations against the enemy and fight the occupier openly without hiding. The process of capturing the Zionist soldier Gilad Shalit and the humane treatment he received from the Palestinian resistance during his captivity in terms of treating his wounds and merely preserving his life is a commitment to the laws of international war. Therefore, Israel is obliged to apply the Third Geneva Convention to protect the prisoners of war of Palestinian prisoners and to grant the prisoner humanitarian and legal rights from the moment of detention until his release and the prisoner may not waive his rights under any pressure exerted by the enemy. ${ }^{52}$

Israel refuses to apply the 1949 Geneva Conventions to the occupied Palestinian territories and does not deal with the Palestinian prisoners under the Geneva Convention, arguing that the status of

\footnotetext{
51 W. Thomas Mallison and Sally V. Mallison, "The Juridical Status of Irregular Combatants": 49.

52 Maher Hijazi, “Aitifaqiat Jinif Althaalithat Lilsujana' Alfilastiniiyn”,Arab Commission for Human Rights, accessed 6 October, 2019, http://achr.eu/old/art785.htm.
} 
prisoners of war applies only to members of the armed forces and members of resistance movements organised by one of the parties to the conflict and that the Palestinian resistance does not belong to any sovereign state and therefore its fighters do not deserve to be held as prisoners of war. ${ }^{53}$

This argument ignores the provisions of Article 4 of the Additional Protocol I of the Geneva Conventions in 1977, which states in its fourth paragraph that the status of prisoners of war extends to armed conflicts in which peoples fight against colonialism, occupation and racism, and the right of people to self-determination enshrined in the Charter of the United Nations and the Declaration on the Principles of International Law and Cooperation among States in accordance with the Charter of the United Nations. ${ }^{54}$

There is a view that according to the Fourth Geneva Convention on civilians during armed conflict or occupation, Palestinian civilian prisoners detained are not prisoners of war. This is supported by the fact that even if the Palestinians are members of armed resistance, they quickly lay down their weapons and return to civilian life once their military action is over and the Palestinian resistance is not affiliated with a state that enjoys the three pillars required by general international law i.e., region, authority, and people. Palestinian prisoners do not enjoy the status of a combatant in the regular army. ${ }^{55}$

Another view is that the use of the term prisoners of war on Palestinian prisoners in Israeli prisons is not the correct legal description and the term that is considered best suited to them is the abductees or hostages. This view is based on the fact that the term prisoner applies only in the presence of a sovereign state at war with another and the prisoners were captured in wartime on the battlefield and this has not happened to most Palestinian prisoners. However, the Israeli occupying forces abduct and arrest the Palestinians from their towns, villages, and places of residence for them to work as hostages.

\footnotetext{
53 Jadallah, "Al'iitar Alqanuniu Limueamalat Al'asraa”.

54 Ibid.

55 New York Convention on the Taking and Abduction of Hostages (adopted 18 December 1979, entered into force 3 June 1983), Art 1(1).
} 
These are considered civilian hostages for the Palestinian people and not prisoners of war. ${ }^{56}$

\section{VIOLATIONS AGAINST THE PALESTINIAN PRISONERS IN ISRAELI PRISONS AND DETENTION CENTERS}

Israel continues to work with security forces, intelligence, and special forces in the practice of physical and psychological torture against the Palestinian detainees during the detention stages, relying on research to explore more effective methods of torture to extract confessions from Palestinians by force, which have had profound negative effects on detained prisoners even after their release. ${ }^{57}$

\section{Physical Violations}

\section{Torture}

The Israeli occupation forces, through their security services, practice various forms of physical torture on the Palestinian prisoners, regardless of men, women, or children, specifically during the execution of arrests and the investigation phase. Systematic torture has been committed against Palestinian prisoners by professional investigators in several means and types. ${ }^{58}$

Palestinian prisoners' arrests are often made by dozens of heavily armed soldiers late at night, without a warrant or real reason. There are many cases in which detainees have been beaten in front of their families, including children. The Israeli army uses silencers during raids without alerting residents, which is in flagrant violation of the privacy of individuals. Detainees and their families are threatened, humiliated, and killed, whereby the furnishing of the house during

56 Abdul Karim Shbeir, "Al'asraa Lildirasat: Almuetaqalun Al'iidariuwn Fi Alsujun Alasarayiyliat Rahayin Yajib Tahriruhum Wataewiduhum", Dunia Al Watan, accessed Sep 8, 2019, https://www.alwatanvoice.com/arabic/content/print/386447.html.

57 Addameer Prisoner Support and Human Rights Association, Violations Against Palestinian Prisoners in Israeli Prisons and Detention Centers in 2013 (Jerusalem: Addameer Prisoner Support, 2013), 27.

58 Essam Abdeen, Munahadat Altaedhib Fi Almawathiq Alduwliat Walwaqie Alfilastinii, (Ramallah: Al-Haq Institution, 2012), 21. 
detention are damaged, including laptops and mobile phones confiscated from homes under attack which are in clear violation of Article 53 of the Fourth Geneva Conventions. ${ }^{59}$ Flagrant violations of detainees' rights resume in Israeli interrogation rooms, as investigators continue the course of attacks that began in the detention process. ${ }^{60}$

The most egregious means of torture are used against the Palestinian prisoners in Israeli prisons such as shaking prisoners, exposing them to cold or heat, random physical beatings, putting them in isolation, subjecting them to psychological stress, sleep deprivation, preventing the use of a toilet, suffocating them with foul-smelling bag and physically, verbally and mentally torturing the prisoners. ${ }^{61}$

These attacks are aimed at destroying the lives of detainees and controlling them mentally and physically and forcing many to criminalise themselves. In recent years, more than 100 different interrogation methods have been observed, with the Israeli authorities constantly attempting to legitimise their internationally banned methods through the use of military orders and several discriminatory laws, specifically Article 2 of the Penal Code of 1972, to justify attacks against detained Palestinians and to provide legal cover for continuing to commit unaccountable crimes. ${ }^{62}$

\section{Medical Negligence and Lack of Healthcare}

With regard to medical care, sick prisoners in Israeli prisons are at great risk as a result of the continued implementation of the policy of medical negligence against them and the lack of real medical care. The Israeli occupation deliberately ignores their treatment and makes them vulnerable to death and incurable diseases, which is a clear violation of the articles contained in the Third and Fourth Geneva Conventions, particularly in Articles 29, 30, and 31 of the Third Geneva Convention,

59 Addameer Prisoner Support and Human Rights Association, Violations of Palestinian Prisoners' Rights in Israeli Prisons in 2015 (Jerusalem: Addameer Prisoner Support and Human Rights Association, 2016), 27.

60 Ibid,23.

61 Sharif Canaanah, Zionist - Israeli Violence and Aggression: Its Aspects, Reasons and Roots, (Ramallah: Center for Studies of Palestinian Heritage and Society, 2010), 445-447.

62 Addameer Prisoner Support and Human Rights Association, Violations of Palestinian Prisoners' Rights in Israeli Prisons in 2015, 23. 
whereas Articles 91 and 92 of the Fourth Geneva Convention. provides for the right of prisoners of war to receive treatment and medical care, appropriate medicines, and full medical examinations periodically. ${ }^{63}$

Contrary to what the Israeli Prison Service and authorities are practicing, their harsh treatment towards prisoners and lack of medical care have resulted in the deaths of some 208 martyrs, eight of whom died after being released due to medical negligence in Israeli prisons. ${ }^{64}$ In addition, the prison administration does not provide prisoners in interrogation and detention centres with personal toiletries such as shampoo, soap, and toilet paper or detergent to clean their rooms, resulting in dirty toilets and poor sanitation. During the interrogation period, which may last for several months, detainees are prevented from bathing, shaving, and changing their clothes. ${ }^{65}$

\section{Strip Searches}

One of the daily violations carried out by the occupation authorities is the naked inspection, a form of humiliation committed by the Israeli forces against the Palestinian prisoners, which is contrary to all international laws and regulations. Prisoners are forcibly restrained and stripped completely by specialised units under the pretext of inspection and search for contraband. During the naked search, clothes are taken for examination and the prisoner is left naked amid the Israeli police as an object of ridicule and sometimes prisoners are collectively stripped naked by jailers. ${ }^{66}$

63 Palestinian Prisoners Center for Studies International Solidarity with prisoners, A Brief Report on the Arrests and the Conditions of Prisoners During the Year of 2018 (Beirut: Palestinian Prisoners Center for Studies International Solidarity with prisoners, 2019), 45.

64 Aqel Salah, “Al'asraa Almardaa Fi Sujun Aliahtilial: Shhid Tilw Shahid”, Dunia Al-Watan, accessed Sep 20, 2019, https://pulpit.alwatanvoice.com/articles/2016/09/29/417428.html.

65 Addameer Prisoner Support and Human Rights Association, Violations Against Palestinian Prisoners and Detainees in Israeli Prisons and Detention Centres in 2007 (Jerusalem: Addameer Prisoner Support and Human Rights Association, 2007), 6.

66 Arab Organisation for Human Rights, The Reality of Palestinian Prisoners in Israeli Prisons in 2013 (London: Arab Organisation for Human Rights, 2013), 13. 
The strip searches are not limited to male prisoners only but also apply to female prisoners. Some released female prisoners have revealed the dangers of naked searches of Palestinian women prisoners in Israeli prisons, as based on prison procedures imposed in central prisons, naked inspection rooms are often under surveillance cameras. ${ }^{67}$

\section{Psychological Violations}

\section{Denial of Visits and Correspondence}

Palestinian detainees are prevented from contacting their families from the moment of their arrest and during interrogation. The International Red Cross and prisoners' lawyers are often not allowed to visit them inside Israeli detention centres during interrogation. In contrast, Israeli prisoners can communicate with their families and lawyers and make one call a day until the interrogation procedure is completed. ${ }^{68}$

\section{Prisoners in Isolation and Solitary Confinement}

Since 1967, the Israeli occupation has been using solitary confinement and isolation against Palestinian prisoners, however, when the prisoners ended their hunger strike on April 17, 2012, the number of prisoners in solitary confinement has increased dramatically thereafter. ${ }^{69}$

The forms and the causes of solitary confinement vary and are used by the Israeli Prison Service as punishment if the prisoner violates prison regulations such as the case of hunger strikers. Solitary confinement is also used as a security measure on the recommendation of Israeli intelligence agencies. The new version of the Israeli Prisons Act of 1971 gives the Israeli Prison Service discretion to assess the type

67 Randa Ahmed, "Al'asirat Alfilastiniaat Yakhdaen Litaftish Ear Fi Sujun Alaihtilal”, Al Jazeera, accessed August 15, 2021, http://www.aljazirah.com/2010/20101025/du16.htm.

68 Addameer Prisoners Support and Human Rights Association, Violations Against Palestinian Prisoners and Detainees in Israeli Prisons and Detention Centers in 2007, 8.

69 Addameer Prisoner Support and Human Rights Association, Violations of Palestinian Prisoners' Rights in Israeli Prisons in 2015, 67. 
and extent of crime and solitary confinement. ${ }^{70}$ It should be noted that the material conditions of solitary confinement are not limited to the isolation of prisoners in isolation cells, but extend to their isolation from the prison yard and means of transport. In addition to that, prisoners are prohibited from any access to bathroom facilities or interacting with any other prisoners. Solitary confinement cells area of $1.5 \mathrm{~m} \times 2 \mathrm{~m}$ or $3 \mathrm{~m} \times 3.5 \mathrm{~m}$ with toilet, mostly not reached by sunlight and poorly ventilated. Meals are served to prisoners through a hole at the bottom of the steel door and prisoners are held in cells for 23 hours a day. Besides, prisoners in solitary confinement are prohibited from communicating with anyone from the outside world and are denied even a minimal social interaction. ${ }^{71}$ Solitary confinement affects the prisoners physically whereas most prisoners after discharge from the cells suffer from gastrointestinal, cardiovascular, and genital diseases. They also suffer mentally. They suffer from panic, tremors, headaches, nightmares, fatigue, heart rhythm disorders, excessive sweating, and shortness of breath. ${ }^{72}$

\section{Financial Blackmail of Families}

Israeli military courts continue the policy of arbitrary detention of Palestinian children and the imposition of heavy fines for their release, as a means of blackmailing, harassing, and draining the financial resources of their families. Although there is no evidence of children being convicted, their release is accompanied by exorbitant fines on their parents of up to 4,000 shekels (about $\$ 1,150$ ), without any regard for the family's financial situation which may prevent them from securing the amount of the fine. The imposition of these sanctions is a long-term punishment for parents, as it causes them to borrow money, as a result, the family may be denied some basic needs. ${ }^{73}$

\footnotetext{
70 Ibid

71 Ibid., 70.

72 Ibid.

73 Addameer Prisoner Support and Human Rights Association, Violations of the Rights of Women and Male Prisoners in Israeli Jails in 2017 (Jerusalem: Addameer Prisoner Support and Human Rights Association, 2018), 27.
} 


\section{Violations in the Field of Religious Rites and Freedom of Worship}

The Directorate of Prisons and the Israeli authorities do not fulfill their primary duty to grant Palestinian prisoners the right to practice their religion, as stipulated under human rights laws and the Third and Fourth Geneva Conventions, which require the detaining power to provide the necessary religious services to prisoners. During detention and interrogation, prisoners are often denied the right to perform their rituals and prayers; instead, they pressure them more psychologically and physically. The prisoners are deliberately interrogated during prayer times and they are also not allowed to access water for ablutions or to access the toilets to prepare for prayer, plus there is no suitable place provided for their prayers, as well as no notification of the direction of the Qibla. Investigators often insult the religious values of the prisoner, insult the symbols and beliefs he or she believes in, and prevent the prisoner from possessing the Qur'an or any religious books. $^{74}$

\section{Violations of the Right to Education and Culture}

The Israeli Prison Service violates Article 94 of the Fourth Geneva Convention, which provides for the right of detainees to continue their education and to provide all necessary facilities. It also violates Articles 26 and 27 of the Universal Declaration of Human Rights, where Israel absolutely prohibits Palestinian detainees from studying in Arab universities and academies and only allows them to study in Israeli universities. This is an obstacle for Palestinian detainees because many of them lack Hebrew language skills. Prisoners are not allowed to practice in certain disciplines, such as physics, chemistry, sociology, democracy, and human rights. In addition, the prison service does not provide the necessary measures and facilities to allow prisoners to continue their education and engage in mental activities. ${ }^{75}$

74 Abd Al-Raouf Mawasi; Hussam Tabaja; Omar Khamaisi, Sarakhaat Min Wara' Alqadbaan: Antihakat Huquq Alasraa Alfilastiniiyn Fi Alsujun Alasarayiylia, (Umm Al-Fahm: Al-Resala for Publishing and Information, 2009), 31-36.

75 Addameer Prisoners Support and Human Rights Association, Violations Against Palestinian Prisoners and Detainees in Israeli Prisons and Detention Centres in 2007, 11. 
The Palestinian detainees are prohibited from accessing computers and other tools, such as typewriters, and can only use textbooks through the Red Cross. There are no special places to study, such as halls or libraries. It should be noted that detainees accused of any violation of prison rules, or who have spent any time in solitary confinement, are prohibited from continuing any educational activities. Some of the detainees told their lawyers that the prison administration did not allow them to pursue their studies because they were punished in solitary confinement. In addition, in 2007, Israel prevented about 3,000 detainees from attending the high school exam and there was no justification for it. It served as a collective punishment against prisoners. The prison administration does not offer any rehabilitation or education programmes for the children of detainees. Many prisoners complain of a lack of books compared to the number of detainees. ${ }^{76}$

\section{Guarantees of Fair Trial}

During 2018, the Israeli occupation legislator continued to pass various laws and legislations aimed primarily at restricting the rights and freedoms of the Palestinian prisoners, such as the enactment of the law on administrative detention, underage detention, force-feeding against prisoners on hunger strike, and restrictions on the lawyers for the Palestinian prisoners. ${ }^{77}$

\section{Administrative Detention}

Administrative detention is a procedure through which the Israeli army is allowed to detain prisoners indefinitely without charge or trial and without any clear reason for arrest, hindering the detainee and his lawyer from providing an effective defence. Administrative detention is usually renewed several times and issued by the executive rather than the judiciary, which is a clear violation of the principles of a fair trial. ${ }^{78}$

\footnotetext{
76 Ibid.,12.

77 Addameer Prisoner Support and Human Rights Association, Violations of the Rights of Women and Male prisoners in Israeli Jails in 2017, 33.

78 Addameer Prisoner Support and Human Rights Association, Administrative Detention in the Occupied Palestinian Territory in 2016
} 
Article 147 of the Fourth Geneva Convention stipulates that detention is only when necessary and for security reasons. The systematic and widespread use of administrative detention is a form of torture. ${ }^{79}$ In accordance with Article 8 (2) of the Rome Statute, the deliberate denial of the rights of the fair and systematic trial of a prisoner of war or any other prisoner is considered a war crime. In addition, the execution of administrative detention orders in closed sessions is a flagrant violation of Article 14 (1) of the International Covenant on Political and Civil Rights, which states that "everyone has the right to hear a fair and public hearing". 80

\section{Stone-throwing Law}

The Stone Throwing Act stipulates that anyone convicted of throwing stones against the background of a national ideology is punishable by 20 years imprisonment or a minimum of 4 years. If a child is convicted of stone-throwing or any security crime because of a national ideology, his or her parents will not receive national insurance benefits for the duration of the sentence. The new version of the law also imposes a fine of up to 10,000 shekels (about $\$ 3,000$ ) against the families of convicted children, a financial burden that weighs on their families amid difficult economic conditions. ${ }^{81}$

\section{Arrest of Children}

The Israeli occupation follows a policy of arresting children under the age of 18 , where they are summoned, arrested, and fined. There are currently 250 children in the Prisons of Megiddo and Auf, as well as others in detention and interrogation centres. According to the 2018 International Solidarity with Prisoners report, there are 980 arrests targeting children under the age of 18 , including those who were shot before being arrested, sick, disabled, and those as young as 12 . The occupation continued to impose administrative detention and high

(Jerusalem: Addameer Prisoner Support and Human Rights Association, 2016), 24.

79 Ibid.,14.

80 Addameer Prisoner Support and Human Rights Association, Violations of Palestinian Prisoners' Rights in Israeli Prisons in 2015, 54.

81 Ibid.,30-31. 
penalties for child prisoners, in addition to imposing heavy fines. This is contrary to the provisions of Article 16 of the Convention on the Rights of the Child, which states: "No child shall be subjected to any arbitrary or unlawful exposure to private life, family, home or correspondence, nor to any unlawful violation of honour or reputation. The child shall have the right to be protected by the law against such exposure or prejudice." However, the Israeli occupation authorities do not abide by these international laws. ${ }^{82}$

\section{Force-Feeding Law - a Legal Cover for Torture}

The Israeli authorities have proposed a law on the forced feeding of prisoners on hunger strike under humanitarian pretexts, claiming that the draft law falls under the responsibility of the Israeli Prison Service to preserve the lives of prisoners by protecting the Palestinian detainee from death or health damage. ${ }^{83}$ This law serves the occupation's political agenda to provide a way out for the prison service without responding to the demands of hunger strikers. Forced feeding orders are issued in closed court sessions and are determined by confidential files to which the detainee and his lawyer are not allowed access. Forced feeding often involves violent and unfair methods against prisoners, causing severe pain, inflammation, tissue damage, and in some cases, the prisoner dies during forced feeding. ${ }^{84}$

Israeli legislator violates laws guaranteed in international treaties and conventions, including the right to self-determination, the right not to be tortured, the right to protest, and the right to refuse treatment. ${ }^{85}$ Malta's Declaration on hunger strike adopted by the World Medical Association also states that "nutrition accompanied by threats, coercion, force or the use of physical restraints is a form of inhuman and degrading treatment." The Tokyo Declaration further states that a

82 Palestinian Prisoners Center for Studies International Solidarity with prisoners, A Brief Report on the Arrests and the Conditions of Prisoners During the Year of 2018, 19-20.

83 Addameer Prisoner Support and Human Rights Association, Forcefeeding under International Law and Medical Standards in 2015 (Jerusalem: Addameer Prisoner Support and Human Rights Association, 2015), 4.

84 Ibid.,5.

85 Ibid., 15-16. 
doctor may not accept, condone or participate in torture, including forced feeding and forced medical treatment of hunger strikers. ${ }^{86}$

\section{Restricting the Work of Lawyers}

The law guarantees the right of a lawyer to visit his client at any hour during the detention centre's working hours without delay. However, Israeli institutions hinder the implementation of the law about the Palestinian detainees and their cases and further issue a decree prohibiting Palestinian lawyers from visiting their clients in the detention centre. ${ }^{87}$

In 2005, 142 petitions were filed with the Israeli Supreme Court to overturn restrictive orders against Palestinian lawyers. The court issued only one decision in favour of Palestinian lawyers and rejected 141 petitions. This is a clear indication of the role of Israeli institutions in violating the rights granted by the force of law. ${ }^{88}$

Although the most important time in communication between a lawyer and a client is the interrogation phase, lawyers are forbidden to communicate with the prisoners during this period, thus adding pressure on the detainee, on top of Israeli investigators' access to data that can be used to complicate the case on the other. These violations committed by the Israeli authorities against the Palestinian lawyers are not limited to the interrogation phase but extend even during the period of detention. ${ }^{89}$

\section{Violations Against Palestinian Women Prisoners}

Since 1967, Israel has arrested more than 10,000 Palestinian women. By the end of 2018, 54 female prisoners were still held in Israeli prisons, including a minor girl; four administrative orders for detention were issued against four female prisoners, two of whom were released during the same year. The female detainees are from various segments

\footnotetext{
86 Ibid.,9-12.

87 Addameer Prisoners Support and Human Rights Association, Violations Against Palestinian Prisoners and Detainees in Israeli Prisons and Detention Centres in 2007, 29.

88 Ibid.

89 Ibid.,30.
} 
of society, such as mothers, doctors, Palestinian Legislative Council (PLC) members, university students, and minors who were school students. ${ }^{90}$

Women prisoners suffer from conditions of detention that violate their rights and do not meet the minimum standards of physical safety and privacy. The testimonies and experiences confirm the serious psychological effects of the search procedures of female prisoners, where some female prisoners reported that they were searched by male soldiers, a particularly arbitrary measure in a conservative Palestinian society. Israeli prison system conducts illegal inspections such as a strip search, while international conventions provide protection and respect for the dignity of women prisoners, specifically Articles 19 and 20 of the Bangkok Rules. Palestinian prisoners do not have privacy because they are always under surveillance cameras in which the cameras cover all detention rooms, prison cells, and bathroom facilities to the point of depriving the prisoners of their basic rights to change clothes and rest. $^{91}$

The Israeli authorities show no concern for the mental state of detainees based on the fact that they are away from their children and families, as well as their social and parental responsibilities. Although Article 26 of the Bangkok Rules stipulates that the communication of entire female prisoners, their children, parents, and legal representatives must be encouraged and facilitated by all reasonable means. However, the Israeli occupation continues to deprive women prisoners of access to their children, husbands, and families in violation of IHL rules regarding the treatment of female prisoners and non-

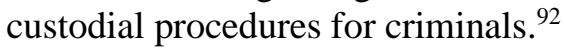

90 Addameer Prisoner Support and Human Rights Association, Violations of the Rights of Women and Male prisoners in Israeli Jails in 2018 (Jerusalem: Addameer Prisoner Support and Human Rights Association 2018), 40.

91 Addameer Prisoner Support and Human Rights Association, Violations of Palestinian Prisoners' Rights in Israeli Prisons in 2015, 85.

92 Ibid., 84. 


\section{CONCLUSION}

IHL has included many international instruments relating to prisoners of war, such as the Third Geneva Convention, which addresses the general recognition of prisoners' classification and their rights. When looking into the rules of international law that highlight the prisoners of war one would assert that they ought to apply in Israel; it is, however, noticeable that these rules do not apply to the Palestinian prisoners in Israeli jails. At the same time, the Israeli occupation still captures thousands of Palestinians in tragic circumstances which are incompatible with international law. Prisoners in Israeli occupation prisons are subjected to the worst forms of torture and ill-treatment in the hands of interrogators. These Palestinian prisoners are subjected to an organised attack that affects all aspects of their lives, by an official Israel decision at the highest level, by the legislature, and the Israel courts to impose more sanctions against them. It is fair to say that the purpose is to double their suffering and leave them with diseases that tear their weak bodies, which eventually lead to the death of many prisoners in the Israeli prisons, including the disregard for the lives of prisoners who have been on hunger strike for months and they may die at any moment. This does not conform to all divine laws and international laws that protect the prisoners and call on to treat them humanely.

Israel denies the right of Palestinian prisoners to seek protection under international conventions on prisoners of war such as the Third Geneva Convention and they treat them as illegal combatants. In addition, Israel uses its internal law, military, and non-military competence to prosecute and torture Palestinian prisoners. Despite the international community's consensus that prisoners should be entitled to many of the rights guaranteed to them in accordance with humanitarian law, they do nothing except condemn the Israeli violations against the Palestinian prisoners without any practical actions to stop these violations. 